\title{
Toxic Effects of Erythrophleum ivorense A. Chev (Bark) on Stem- Borer Insect Pest on the Growth and Reproductive Stages of Maize Plant (zea mays)
}

\section{Akhideno L.O. ${ }^{1}$, Ogboru R.O. ${ }^{2}$ and Owoeye E.A. ${ }^{1}$}

${ }^{1}$ Forestry Research Institute of Nigeria; Moist Forest Research Station, P.M.B 2444, Benin-city.

${ }^{2}$ Forestry Research Institute of Nigeria: Research Control Unit, Jericho Hills, P.M.B. 5087, Ibadan.

$\begin{array}{ll}\text { ARTICLE INFO } & \text { ABSTRACT }\end{array}$

Article No.: 102817159

Type: Research

DOI: 10.15580/GJAS.2017.10.102817159

Submitted: $28 / 10 / 2017$

Accepted: 03/11/2017

Published: 16/12/2017

${ }^{\star}$ Corresponding Author

Akhideno L.O.

E-mail: lawsonakhideno@yahoo .$c 0 m$

Keywords:

Erythrophleum ivorense, (steep

water extract) maize, stem borer

and Bio-pesticides
Erythrophleum ivorense efficacy of its steep water extract to control yellow stem borer in maize plant during the growth and vegetative stages was investigated in the Science laboratory Department of Federal Polytechnic, Auchi, Edo State, Nigeria. The extract (steep water) was applied at the rate of 0 (control), 5, 10, 15 and $20 \mathrm{mlkg}^{-1}$. The result obtained showed that Erthrophleum ivorense (water extract) at $10 \mathrm{mlkg}^{-1}$ to $20 \mathrm{mlkg}^{-1}$ were effective in the control of stem borer at $0.01 \%$ level of significance. It also revealed the strong insecticidal action of $E$. ivorense on maize insect pest. However, with increasing concentration of the $E$. ivorense at $20 \mathrm{mlkg}^{-1}$, giving the highest mortality rate residual action and the reproductive at $89.15 \%, 76 \%$ and $0 \%$ respectively. This finding provides a good resource for poor farmers in developing countries who will find this trial affordable than buying chemical pesticides. 


\section{INTRODUCTION}

Agriculture is the moral fiber of man's survival on earth, but pests, diseases and weeds are recognized as major constraints to crop and livestock production (FAO., 2006). Insect pest damage to field and stored grains result in major economic losses and a nation where grain production support the livelihood of majority of the population (Jose and Adesina, 2013). Grain loss caused by pest in the field such as maize pest (Army worm and stem borer) is a severe issue to farmers. Udo (2000) reported that pests and many others threaten food security. He also reported that pest damage during vegetative stages if not controlled, becomes a serious problem to the economy. Cereal crops. especially maize is widely attacked by grain weevil Sitophilus zeamais causing $25-100 \%$ postharvest losses in storage (Okonkwo, 1998). The stem borer is one of the major insect pests that attack maize during the growth and flowering stages. It is a major threat to the maize production in Nigeria and Africa causing 100\% damage. Koehler (2002) reported that, owing to their insidious feeding habits, they damage the crop plant fast.

However the losses resulting from the feeding activities and damage of the maize, it is essential that a necessary control measure is put in place to ensure adequate maize production and storage.

Insect pest control in field and stored food products has relied heavily on the use of gaseous fumigant and residual contact insecticides. Similarly, the European Union has criticized the use of chemicals in the control of insect pest on the field and storage, resulting in residual effects to humans (Murugan, 2006). Thus, this problem has created the need to find materials that will effectively protect field plant and stored grains, that are readily available affordable, relatively, less poisonous and less detrimental to the environment. The use of different plant materials to protect, stored and field plants against pest infestation by mixing grain or spring with Protestants made up of plant products. This plant material that used to protect agricultural products against variety of insect pests is an old-age method in some parts of the world (Peter 1985; Ulebor and Onolemhemhem 2002).

Erythrophleum ivorense is an important ingredient for compounding insect pest infestation in the growth and vegetative stages in plant. Erythrophleum ivorense belongs to the family caesalpiniacae (Leguminosae caesalpinioideae). It is a timber plant and it is marketed as lyin in Edo, Erun in Yoruba, Ihi in Igbo (Aigbokhan, 2014 and Ogboru et al., 2017).

In the light of the above, natural plant material Erythrophleum ivorense which is in abundance in the rain forest vegetation belt has some potentials in protecting our maize plant during growth and reproductive stages, which can be harnessed in the form of water ( bark of Erythrophleum ivorense soak in water ) for use as bio -insecticides. The achievement in this direction will help to increase the scope of maize production and its utilization to meet up with the ever increasing demand for maize products.

This trial is aimed to determine the efficacy of this plant materials in the control of insect pests especially stem borer in the growth and vegetative stages of maize plant.

The specific objectives of the study were to ascertain the efficacy of Erythrophleum ivorense (steep water) in the control of stem borer pest of varied treatment levels, to determine the residual effect of Erythrophleum ivorense (steep water) in the control of stem borer and other agricultural field pests at varied treatment levels and to undertake a study of the efficacy of stem borer mortality at varied levels of treatment.

\section{MATERIALS AND METHODS}

The experiment was carried out at science laboratory department, Federal Polytechnic, Auchi, Edo State located at latitude $6^{0} \mathrm{~N}$ and longitude $6^{0} 2^{0} \mathrm{E}$ with hot humid tropical climate. The adult stem borer were obtained from naturally infested maize plant from the farm. They were cultured for the study.

\section{Plant Material}

The bark of Erythrophleum ivorense was collected from Ozalla forest in Owan-West Local Government Area of Edo State. The bark was dried to a constant weight of $60^{\circ} \mathrm{C}$ in an oven. The dry material was soaked in water for 3 days and the water was used as a test plant material (insecticides).

The test material (water) from the Erythrophleum ivorense was admixed or sprayed at different rates $(0,5$, 10,15 and $\left.20 \mathrm{mlkg}^{-1}\right)$. The 0 application is the control. Maize was planted into a poly bags. There were three replicate for each experiment set up. All treatments were arrayed using the randomized complete block design. Five weeks after planting (5 WAP) twenty maize plant was infested with the stem borer. The following parameters were taken:

\section{Mortality:}

For motality studies, the maize plant were treated with the insecticide (water from $E$. ivorense) at different rate $\left(0,5,10,5,15\right.$ and $\left.20 \mathrm{mlkg}^{-1}\right)$. The mortality of the stem borer was 15 days. We also observed if a fresh leaf of the maize will come out without damage and with white powder around the maize cap. After which all surviving adults were removed as suggested by Ivbijaro (1990), Onolemhemhem and Oigiangbe (1991).

\section{Reproductive Capacity}

Effect of $E$. Ivorense (water) on the reproductive capacity 
of adult maize stem borer was also investigated 20 days after infestation to reveal the egg plugs of the stemborer. Progency emergences were recorded from 25 days after infestation until 60 days after infestation.

\section{Residual effect of the test material}

The test material for this purpose was infected with the stem borer insect pest at 5, 15, 35, 45 and 50 days after application. The mortality of the test insect pest was determined by daily mortality counts. The reproduction of the test insect pest was also studied using the method and opted by (Ivbijaro, 1990, Amisan and Okorie, 2002 and Ulabor and Onolemhemhem 2002).

Data collected were subjected to Analysis of variance (NOVA) using the Genstat Release 8.1 statistical software and the means separated using Turkey's Test at $1 \%$ level of significance.

\section{RESULTS}

Effect of Erythrophleum ivorense (soak water) in stem borer insect pest mortality in maize

The results of the bio active of Erythrophleum ivorense on stem borer mortality is presented in table 1. The data shows that the water of Erythrophleum ivorense at rates applied caused mortality of the stem borer adults. Barely 24 hrs after infestation, the plant material caused mortality which ranged from 0.00 to 16.00 , with $20 \mathrm{~m} / \mathrm{kg}^{-}$ ${ }^{1}$ used recorded the highest mortality value. At $120 \mathrm{hrs}$ after treatment, the mean recorded on mortality ranged from 2.00 to 20.00 with the control recording the least and the $20 \mathrm{~m} / \mathrm{kg}^{-1}$ recorded the highest value. There was significant difference in treatment means $(P<0$. 001).

Table 1: Effect of Erythrophleum ivorense on army worm pest mortality $E$.

\begin{tabular}{cccccc}
\hline $\begin{array}{c}\text { Ivorense } \\
\text { (Soak water) }\end{array}$ & $\mathbf{2 4} \mathbf{~ h r s}$ & $\mathbf{4 8} \mathbf{~ h r s}$ & $\mathbf{7 2} \mathbf{~ h r s}$ & $\mathbf{9 6} \mathbf{~ h r s}$ & $\mathbf{1 2 0} \mathbf{~ h r s}$ \\
00 & $0.00^{\mathrm{a}}$ & $0.31^{\mathrm{e}}$ & $1.00^{\mathrm{a}}$ & $2.00^{\mathrm{e}}$ & $2.00^{\mathrm{e}}$ \\
5.0 & $8.61^{\mathrm{c}}$ & $10.32^{\mathrm{a}}$ & $11.34^{\mathrm{c}}$ & $12.01^{\mathrm{a}}$ & $13.92^{\mathrm{a}}$ \\
10.0 & $14.62^{\mathrm{b}}$ & $15.01^{\mathrm{c}}$ & $15.87^{\mathrm{a}}$ & $16.63^{\mathrm{b}}$ & $16.54^{\mathrm{c}}$ \\
15.0 & $15.07^{\mathrm{a}}$ & $16.42^{\mathrm{a}}$ & $17.63^{\mathrm{a}}$ & $18.19^{\mathrm{a}}$ & $19.00^{\mathrm{b}}$ \\
20.0 & $16.00^{\mathrm{a}}$ & $17.87^{\mathrm{a}}$ & $18.41^{\mathrm{a}}$ & $19.57^{\mathrm{a}}$ & $21.10^{\mathrm{a}}$ \\
Means & 11.01 & 12.00 & 13.02 & 14.30 & 14.81 \\
LSD & 0.60 & 0.74 & 1.40 & 1.90 & 0.87 \\
CV\% & 2.90 & 3.10 & 5.10 & 4.40 & 0.53 \\
\hline
\end{tabular}

Note: Means following by same letter within a column are not significantly different at $1 \%$ level Residual effects of Erythrophleum ivorense on stem borer insect pest in maize.

The result in table 2 shows the residual effects of $E$. ivorense on stem borer pest in maize. The data indicated that 5 days after treatment, the residual toxicity caused the stem borer mortality which ranged from 0.65 to 10.33 with $20 \mathrm{~m}-\mathrm{mlkg}^{-1} \mathrm{lkg}-1$ treated plant recording the highest mortality value.
By 55 days after treatment, residual toxicity means mortality recorded ranges from 0.33 to 4.07 , with the control (0) recording the least mortality data, while the $20 \mathrm{mlkg}-1$ recorded the highest value as the army worm insect pest were completely gone. The difference between treatments means were significant $(P<0.001)$.

Table 2: Residual effect of Erythrophleum ivorense on stem borer insect pest on maize

\section{E.invorense}

(water)mlkg-1

\section{0}

5.0

10.0

15.0

20.0

Means

LSD

CV\%

5days

$0.65 \mathrm{e}$

$5.01 d$

$7.08 \mathrm{c}$

$19.00 \mathrm{~b}$

$10.33 a$

7.50

1.27

9.1

15 days
$0.06 \mathrm{~d}$
$4.00 \mathrm{c}$
$5.21 \mathrm{~d}$
$8.87 \mathrm{a}$
$9.92 \mathrm{a}$
5.32
1.31
12.1

12.1

\begin{tabular}{l}
25 days \\
\hline $0.07 e$ \\
$3.54 d$ \\
$5.31 \mathrm{c}$ \\
$6.54 \mathrm{~b}$ \\
$9.01 \mathrm{a}$ \\
4.73 \\
1.30 \\
13.1
\end{tabular}

35

35 days

45days 50days

\begin{tabular}{cll}
$0.31 \mathrm{~d}$ & $0.05 \mathrm{~d}$ & $0.33 \mathrm{e}$ \\
$2.43 \mathrm{c}$ & $2.30 \mathrm{c}$ & $1.01 \mathrm{~d}$ \\
$4.51 \mathrm{~b}$ & $3.41 \mathrm{c}$ & $2.51 \mathrm{c}$ \\
$5.32 \mathrm{~b}$ & $5.01 \mathrm{~b}$ & $3.42 \mathrm{~b}$ \\
$7.30 \mathrm{a}$ & $7.00 \mathrm{a}$ & $4.07 \mathrm{a}$ \\
4.03 & 3.51 & 2.37 \\
1.33 & 1.60 & 0.57 \\
16.2 & 25.1 & 12.5 \\
\hline
\end{tabular}


Effect of Erythrophleum invorense extract (water) on the Reproduction capacity of stem borer insect pest in maize

The data in table 3 below shows that there are significant $(P<0.001)$ differences in the treatment means as it affected the life cycle of the stem borer insect pest. After treatment, the number of emergent adults ranges from 0.00 to 19.0 , with the control (0) recording the highest number of 19 adults emergence from the egg plugs, while $20 \mathrm{mlkg}-1$ recorded zero emergence.

Table 3: Effect of Erythrophleum ivorense extract (water) on the Reproduction capacity of stem borer insect pest on maize

\begin{tabular}{llll}
\hline $\begin{array}{l}\text { E. Invorense water (mlkg-1) } \\
\text { Lifecycle }\end{array}$ & No of egg plugs & No of emergent adult & Length \\
\hline 0.0 & 21 & 19 & $25.00 \mathrm{a}$ \\
5.0 & 16 & 7 & $32.00 \mathrm{a}$ \\
10.0 & 6.0 & 2 & $38.00 \mathrm{~b}$ \\
15.0 & 0.0 & 0.0 & $0.00 \mathrm{c}$ \\
20.0 & 0.0 & 0.0 & $0.00 \mathrm{c}$ \\
Means & & & 16.20 \\
LSD & & & 4.03 \\
CV\% & & & 3.10 \\
\end{tabular}

\section{DISCUSSION}

The effectiveness of Erythrophleum ivorense (bark) used in the experiment showed a significant difference in the control of stem borer insect pest in maize plant at different level of treatment $E$. ivorense (bark) proved effective in the control of stem borer insect pest at the treatment rates of $10 \mathrm{mls}$ to $20 \mathrm{mlkg}-1$ especially after 96 hours and 120 hours of treatment. It was observed that with high level of the extract (E.ivorense bark) used, the higher the number of dead stem borer insect pest recorded. This finding is similar to the earlier work of Abdullahi and Mohammed, 2003 and Udo 2005, which stated that increase in the concentration of the plant material caused increased mortality of the insect pest.

The plant material extract of Erythrophleum ivorense bioactivity has significant $(p<0.001)$ effect in the reproductivity capacity of stem borer insect pest at the varied rate of treatments. The effectiveness in the control of the reproductive capacity may be due to its chemical compositions, persistence and susceptibility of the insect to the plant material. The toxicity, chemical composition, accounts for its effectiveness in the control of stem borer insect pest progeny emergence. The toxicity and chemical composition is also effective in reducing oviposition substantially, this is in accordance with Amusan and Okorie (2002).

The residual toxicity of $E$. invorense to stem borer insect pest at the varied treatment rates and period are significant $(p<0.001)$. The residual toxicity effect of the plant extract on stem borer mortality could be due to its poisonous insecticide constituent. Supporting to this claim, Udo (2005) reported that $62 \%$ to $63 \%$ insecticide action can be toxic, irritating and persistence. Also, Amusan and Okorie (2002), Ulebor and Onolehemhem,
(2002) agreed that the highly toxic, poisonous nature, persistence and other constituent components could account for the treatment residual toxicity effects on the stem borer and other insect pest.

The result of the application shows that $E$. ivorense extract could be used to control pest in the field. It was observed that the use of this plant material extract has no adverse effect on the morphology of the maize plant. Amusan and Okorie 2002, Abdullahi and Mohammed 2003 and Udo 2005.

\section{SUMMARY, CONCLUSION AND RECOMMENDATION}

The result obtained from this study indicates the potentials of using plant material (forest plants) as pest management systems. The Erythrophleum ivorense used in this study is just insect pest control, readily available, safe to apply and can be afforded by our poor resource farmers. However, botanical pesticides/insecticides represent important potential for integrating insect pest management programmes, for as much as they are local materials that can readily be sourced. The bark of Erythrophleum ivorense has been discovered to have appreciable amount of toxic substances that can fight and reduced insect pest in the growth and vegetative stages of maize plants. It also recommended that, further research work should be carried out on Erythrophleum ivorense to increase the scope of available botanicals for insect pest management.

\section{REFERENCES}

Abdullahi, Y.M and Muhammed,S. (2003). "Assessment of the toxic potential of some plant powders on survival and development of callosobuchus 
maculates." Department of Biological Science, Usmanu Danfodiyo university sokoto, Nigeria.

Amusan and T.G Okorie (2002). The use of piper guineense fruits oil (PTO) as protectant of dried fish against Dermestes maculatus (Degree) infestation published in the Global journal of pure and Applied Science vol 8, No 2.

Aigbokhan, E.I (2014). Annotated checklist of vascular plant of southern Nigeria. P9 86:211 FAO (2006): FAOSTAT; Food and Agriculture, Database result.

Ivbijaro, M.F (1990): Toxic effects of groundnut oil in the rice weevil, sitophilus oryzae. Insect Science and its Application,5(4)251-252.

Ivbijaro, M.F (1990): Efficiency of seed oil of Azadirachta indica $\mathrm{A}$. juss and piper guineense schum and thonn on the control of

callosobruchus maculatus $F$. insect science and its Application 11(2):149-152.

Jose, A.R. and J.M. Adesina (2013). Damaged suppression of stored maize infested by maize weevil using Bridellia micrantha and Chasmanthra dependens leaves powder. Proceedings of the $47^{\text {th }}$ Annual Conference of the Agricultural society of Nigeria.Pp 38-41

Koehler, P.G (2002). Rice weevil, sitophilus oryzae (coleoprera curculionidac). Entomology and Nematology Department.

Cooperation Extension Service, Institute of food and Agricultural Science, University of florida, Geinesvilla, 326:11.

Murugan, K. (2006). Biopesticides as environmentally soft tool for the management of insects/ mosquito vectors. Int. symp. On Biocont. And Biotech. Madurai. P.34

Ogboru R.O., Akhideno, L.O. and Owoeye, E.A. (2017): Chemical Composition and medicinal potentials of the bark of

Erythrophleum ivorense A. Chev. Journal of Bioscience and Biotechnology Discovery. 2:15-20

Okonkwo, E.U (1998): Bibliography. A bibliography of plant materials used for controlling insect pest of stored products in Nigeria. Review of Agricultural Entomology 30pp

Onolemhemhem, P.O and Oigiangbe, C.N (1991): Biology Callosobruchus Maculates (fabr) on cowpea (vigna unguiculata) and pigeon pea (cajanu scajan L .Druce) treated with vegetable oil and Thriol samoru Jor Agricultural Resources 8:57-63.

Peter, D.S. (1985): An introduction of insect pest and their control. Macmillan press Ltd pp1-73.

Ulebor, J.A. and Onolemhemhem, P.O (2002). Laboratory investigation on xylopia aethiopica and piper guineense seed powder and oil extracts on the of sitophilus oryzae M.Sc Thesis, Ambrose Alli university, Ekpoma 61pp.

Udo, I.O (2000): Efficacy of candle wood Zanthoxylum Xanthoxyloide Lam, for the control of three stored product pests. M. phil. Thesis University of Ghana Legon, Accra 81pp.

Udo, I.O (2005): Evaluation of the potential of some local spices as stored grain protectants against the maize weevil, sitohilus zeamais mots (coleopteran curculiondae). Journal of Applied Science and Environmental Management vol 9. No1, pp165- 168.

Cite this Article: Akhideno LO, Ogboru RO and Owoeye EA (2017). Toxic Effects of Erythrophleum ivorense A. Chev (Bark) on Stem-Borerlnsect Pest on the Growth and Reproductive Stages of Maize Plant (zea mays) Greener Journal of Agricultural Sciences, 7(10): 289-293, http://doi.org/10.15580/GJAS.2017.10.102817159. 